\title{
Indonesia, modernity and some problems of religious adaptation
}

\author{
JUNE MCDANIEL
}

\begin{abstract}
${ }^{1}$
This article discusses the challenges of adaptation for Indonesian religion. It describes the ways that the major Indonesian religions have changed to fit the requirements of being recognized religions, and focuses as an example on the ways that Balinese Hinduism has changed to become Agama Hindu Dharma Indonesia. It also examines the traditional theological problem of "faith and works" in the Indonesian context, and the concerns used to balance modernization and religious freedom.
\end{abstract}

KEYWORDS

Indonesian religions, religious adaptation, Hinduism, Islam, theology.

The country of Indonesia has developed a unique method for having different world religions get along with each other. They have had religious leaders rewrite and reinterpret these traditions into clear and unambiguous monotheisms, so that they can find common ground, as they all worship the same one God. This form of religious and political universalism shows the world a religious philosophy which has great potential for tolerance and dialogue. As prominent Indonesian Muslim writer Nurcholish Madjid has noted, all people who worship and submit to one God can be called Muslims - this is the meaning of the word Muslim, from salaam. Therefore, members of all world

1 I wish to thank all of the scholars who were willing to spend their time in these interviews about religion in Indonesia. They have all contributed greatly to intercultural understanding, and they were all gracious and thoughtful in the process.

JUNE MCDANIEL is Professor History of Religions at Department of Religious Studies, College of Charleston. Her major research interests are concerned history of religions (world religions, myth, ritual and symbol, history and methods of the discipline); religions of India, mysticism and religious experience, cultural history of South Asia, psychology of religion. Her important publications are "Agama Hindu Dharma as a new religious movement: Hinduism recreated in the Image of Islam" (Nova Religio, 2010, 14(1): 93-111) and Making virtuous daughters and wives; An introduction to the Brata rituals of Bengal (Albany: State University of New York Press, 2003). June McDaniel may be contacted at: mcdanielj@cofc.edu. 
religions accepted as monotheistic can be understood as legitimate believers, and as equals before God.

Indonesia has the largest Muslim population in the world, and a policy of declaring only monotheistic religions as legitimate and sanctioned by the government. In order to be accepted, Indonesia's major religions have been changing. They have all been adapted into ethical monotheisms, fulfilling the government's requirements for a single almighty God, a sacred text, a prophet, and a universal ethic. ${ }^{2}$ This allows for an expansion of "the people of the book", a way for the Muslim majority to develop a strategy for peace building. This paper will examine this process of adapting world religions, focusing on Indonesian Hinduism, and examine some related concerns.

In most interfaith dialogue, one goal is religious toleration of theological and ritual differences. Religions are "separate but equal" with some cross-cultural commonalities but no common core. The perspective of religious universalism, of "one God portrayed in different ways by different cultures", is rare these days, especially in the American field of Religious Studies, where the emphasis is on area studies and historical uniqueness. Interest in theological unity tends to found in the interfaith movement, and in Christian ecumenicalism. ${ }^{3}$ However, we do see the idea of unity of religions institutionalized in the constitution of Indonesia, through the Pancasila, intended to unify a wide range of tribal groups, kingdoms and societies that had no common language, currency, or culture. The term Pancasila comes from two Sanskrit words, panca 'five' and sila 'principle'. The other principles of the Pancasila, found in the Indonesian constitution, include a just and civilized humanity, the unity of Indonesia, democracy, and social justice. The goal was to build nationalism, and discourage ethnic loyalties. ${ }^{4}$

These principles declare the non-secular basis of modern Indonesian

2 There is some debate about the requirement for a prophet. According to practitioners in Indonesia, Hinduism accepts Vyasa as a prophet, Buddhism accepts the historical Buddha Siddhartha Gautama, and Confucianism accepts the historical figure of Confucius. All of these preceded Mohammad. In interviews, I was told that having a prophet was a requirement for acceptance as a religion.

3 In the United States, there are two different ways that religion is studied. In the public universities, it is studied as a system of belief and practice, a way of life that contributes to a culture. This is known as the academic approach to Religious Studies. In private religious schools, religion is studied for truth claims, and the interest is in which religion a person should follow, and how to properly practice it. This is known as the theological approach to Religious Studies. They are generally separate, as the first amendment to the US constitution emphasizes religious freedom, and no establishment of religion. Thus, the academic and theological approaches are opposed.

4 In its earlier draft form the preamble to the Constitution contained the Jakarta charter, which stated that Indonesian Muslims must follow sharia (Islamic religious law), and that the president must be Muslim. The Pancasila was a compromise between nationalist Muslims, who wanted a Muslim state, and the demands of other religions. When the 1950 finalized version of the constitution did not include the Jakarta charter, radical Muslim groups (which we would later categorize as Islamist) broke off, creating the Darul Islam movement arguing for an Islamic state of Indonesia. It motivated the creation of later Islamist splinter organizations, such as the Commando Jihad group. 
statehood, emphasizing religious tolerance as a sacred duty. Indonesia as a republic has a religious foundation, but not a narrow one. Human rights are understood as gifts from God, and the basis of Indonesian national unity is its belief in One God (Tuhan Yang Maha Esa 'One Supreme God'). Thus, the constitution and the law are based on religious faith. ${ }^{5}$ Indonesia consciously avoids the labels of either a theocracy (with its danger of extremism) or a secular state (with its danger of communism); it defines itself as a religious state. ${ }^{6}$

Religion has been used to unite diverse cultures before - perhaps the most well-known example was the emperor Constantine (and Theodosius after him) who unified the Roman Empire through the shared religion of Christianity. Constantine summoned the first councils that decided Christian canon, doctrine, ritual, and organization. As early Christianity was based on scattered books, letters, and oral traditions, it was important to forge a consensus of ideas and sacred texts. ${ }^{7}$ Constantine began the process of creating a single, standardized religion, with a standardized Biblical text that people could follow all over the Roman Empire. This was intended to unify the empire. Indonesia, on the other hand, has created a standardized definition of religion, into which a wide variety of belief systems could fit, and be accepted as equals. This was intended to unify the country.

The definition of a legitimate religion was determined and standardized by the Departmen Agama (the Ministry of Religion) founded in 1946. A religion needed to have one God-the deity could have any name, but it needed the correct number, which was only one. It needed a prophet or prophets, and a sacred text which were revealed by God to the prophet. It needed a universal ethic, which meant that its moral rules were not limited to a particular cultural group, but applied more broadly to all of its religious followers. It should be recognized as a world religion, and not a local or ethnic one. These requirements have fluctuated over the years, but the one God, with text, has remained significant.

While this was initially intended to emphasize the dominance and universal truth of Islam, it became over time a framework for religious pluralism. Both Catholic and Protestant Christianity could fit into the definition, emphasizing the Unity rather than the Trinity of God. However, the Eastern religions have required more adaptation. Hinduism has become an Indonesian religion, Agama Hindu Dharma Indonesia, with the sages (rishis) as prophets, and the Vedas and the Gita revealed by the one God, who is called Sanghyang Widhi Wasa. Following its lead, Indonesian Buddhists claimed a monotheistic God, Sanghyang Adi Buddha, with the historical Buddha Gautama as his prophet. The tradition of Buddhayana eventually became accepted as a monotheistic

5 Efimova (1996: 55).

6 These concerns about communism and extremism are noted by many Indonesian writers, both official and in the opinion pages of Indonesian newspapers, up to the present day.

The Biblical canon was organized by Athanasius and Eusebius, and affirmed at the Councils of Hippo and Carthage in the latter fourth century. 
Indonesian religion, Agama Buddha. More recently, Confucianism or Agama Konghucu has been accepted as a religion, with Tian or Shang Ti as its monotheistic God, and the Analects and other texts of the Chinese Ru tradition as revealed sacred texts. Confucius, or Kongfuzi, is the last of the prophets of the $\mathrm{Ru}$ tradition, or one might say the seal of the prophets.

These adaptations were necessary, as only members of religions accepted by the government can get government benefits, such as the Identity Card (required for voting and passports), legal marriage rituals and religious holidays. Religions which are not accepted by the government, known as the aliran kepercayaan or streams of belief, can practice their traditions, but they often have trouble getting an Identity Card. ${ }^{8}$ This means that they cannot get various government benefits. While the government has officially ceased requiring a religion on the identity card, in practice, local representatives still usually require it, and it has been difficult for minority religions to register births, marriages and deaths. ${ }^{9}$

To adapt to the political definition of religion, all religions have been willing to sacrifice. The Western religions have largely sacrificed practices, while the Eastern religions have sacrificed doctrines. Muslims have had to give up the creation of a national sharia law, and the requirement for all presidents of Indonesia to be Muslim. ${ }^{10}$ Islam was not declared to be the official national religion of Indonesia. Protestant and Catholic Christianities have had to give up evangelizing to members of other accepted religions, and building churches in neighbourhoods dominated by other accepted religions (especially Muslim ones). These limitations have caused much religious tension. Hinduism had to develop a high God that was unique to Indonesia, and a monotheistic theology. Buddhists had to develop a deity (a challenge to a largely non-theistic religion), while Confucians needed both a deity and an understanding of Confucianism that did not emphasize the importance of China as a sacred place.

The major form of Islam in Indonesia follows the Syafi'ite legal school. From an international perspective, perhaps the most important aspect of this interpretation is its ability to compromise. Indonesia's former president, Abdurrahman Wahid, gave a useful argument for peace from this perspective to many radical groups who were used to the idea of the world being divided into two camps, dar al-Islam (the world of Islamic peace), and dar al-harb (the world of war against Islam). Wahid emphasized that within the Sunni Shafi'ite legal school, there are actually three legitimate kinds of state: Islamic (dar al-

8 Recently, the government announced that religion was no longer necessary for the identity cards, but this has not always worked out in practice. People with unaccepted religions are still having trouble getting identity cards, especially in rural areas.

9 Silalahi and Lindholm (2010: 27-28). Also, interviews with representatives of MADIA Society for Inter-faith Dialogue, 2010, and see International Religious Freedom Report (2011: $5,9)$.

10 These were tried, most notably through the attempt to include the Jakarta Charter in the 1945 Constitution. 
Islam), anti-Muslim (dar al-harb), and states at peace with Islam (dar al-sulh). ${ }^{11}$ He argued that Muslims only need to fight enemies, not those who wish peace and were willing to cooperate with Muslims. This gives a legitimate legal argument for Muslim peaceful coexistence with other religions.

This is important in modern Islam, because there has been heavy pressure on modern Indonesia from more radical forms of Islam, which have penetrated the media and the universities, and are funded by wealthier and more Islamist Muslim countries. There are public rallies, theatre performances, billboards and television advertisements, and newspaper editorials in favour of stricter Muslim law and the eventual use of sharia. Thus far, public opinion has not been swayed by it, though jilbab (headscarves) for women have spread throughout the country in the last ten years as a statement of conservative Muslim belief. ${ }^{12}$ Indonesia has consistently voted down the attempts by Salafi factions to create an Islamic state. This is seen by some Muslim groups as sacrificing the advantages of being a majority.

Besides the denial of an Islamic state, some conservative Muslims in Indonesia were angered because the rule of sharia did not apply to more liberal forms of Islam. These are the kebatinan groups, who incorporate Hindu, Buddhist, Sufi, and animist beliefs and rituals into Muslim practice. These are considered to be unacceptable innovations. More extremist Muslims also wished to delegitimize forms of Islam deemed heretical, such as the Ahmadiyya adherents, who believe in a prophet after Muhammad. There have been protests against them, with the closing of their mosques and violent riots. Such violence is illegal, though the police do not always enforce the law and defend them.

Christians in Indonesia have had to emphasize the unity of God, rather than the Trinity, and they have also been limited in terms of conversion. They have been prohibited from evangelizing and missionary work with people who already belong to an accepted religion, and from building churches in many areas. Both priests and ministers have tried to find ways to adapt to these limitations, and one approach has been the theological equating the Christian God and Christian worship rituals to the rituals of other religions, especially Islam (describing churches as worshipping Allah).

In Indonesia, Christianity is split between Catholic and Protestant religions as two legally separate entities, a separation begun by the Dutch. Christians of either sort cannot build churches freely-permits for houses of worship need signatures of sixty residents, but even with these signatures, church permits have been denied..$^{13}$ Attempts to have home churches (group worship within

11 Intan (2006: 97).

12 While headscarves may occasionally be used for fashion statements in Indonesia, this is virtually never seen in the USA and Europe. Headscarves there mean the person is following a conservative brand of Islam, and more liberal Muslim women usually do not wear headscarves.

13 See Camelia Pasandaran, "Another church faces closure amid hard-line protest in West Java", The Jakarta Globe, 20 March 2014, at http://www.thejakartaglobe.com/news/ another-church-faces-closure-amid-hard-line-protest-west-java/. 
private homes) have resulted in protests and riots. However, Christians are allowed to send missionaries and preach to members of non-official religions, and build churches on their land.

As Fr. I. Ismartono has noted, Catholics often call themselves Sahabat Insan 'friends of humanity'. They are willing to work with all groups against common problems, like illegal trafficking, abuse of workers, and regional conflicts. But modern Catholic practitioners must be careful that charity is not misinterpreted as proselytizing. ${ }^{14}$

Theological adaptations have been a source of conflict within Christianity as well. Fr. Daniel Byantoro, an Indonesian priest who has been organizing the Indonesian Orthodox Church, has encountered opposition from the Greek and Russian Orthodox churches from proceeding because he wishes to include Indonesian styles of music, imagery on icons, and liturgical dress. From the perspective of the Indonesian Orthodox Church, God is one but has three aspects. The Father represents the infinite existence of God; as son or Logos, Jesus represents the word or mind or God; and the Holy Spirit represents God's love. $^{15}$

Buddhists have had a particularly hard time with this definition of religion, partly because most forms of Buddhism are non-theistic, and partly because there are dozens of Buddhist factions in Indonesia that disagree with each other. ${ }^{16}$ A form of Indonesian Buddhism called Buddhayana was able to incorporate the other forms of Buddhism under an umbrella of monotheism. There has been much disagreement over this, with Buddhist organizations rapidly coming into and out of existence (perhaps demonstrating the Buddhist concept of impermanence). Some accept the notion of a deity, while others try to simply focus on ethics.

Buddhism became an accepted religion indirectly, starting as a subcategory of Hinduism. There have been many forms of Buddhism practiced in Indonesia, including Theravada, Mahayana, Tantrayana, Tridharma, Maitreya, and Nichiren. The Buddhayana group is non-sectarian and incorporates the other forms of Buddhism. Its founder, Bhikku Ashin Jinarakkhita, proposed in 1954 that there was a single supreme deity, Sang Hyang Adi Buddha, basing his argument on ancient Javanese texts, and on the shape of the Buddhist temple complex at Borobudur. The earthly figure of Gautama Buddha was considered to be the prophet of the God Sanghyang Adi Buddha, and the universal ethic of Buddhism was based on the four noble truths. Buddhism began its official separation from Hinduism in 1965, though its theological

14 Interview with Fr. I. Ismartono, SJ, coordinator of the Catholic Crisis Center, Jakarta, 2010.

15 Interview with Fr. Daniel Byantoro, founder and president of the Gereja Orthodox Indonesia (Indonesian Orthodox Church), Solo, 2010.

16 Some forms of Mahayana Buddhism may be considered to be theistic, especially the Pure Land tradition of Japan and China. According to the major Pure Land theologies, Amida Buddha comes down from his heaven to bring worshippers into his paradise, where they will live in happiness, and he takes away their sins. There has been much debate about Christian influence on Pure Land Buddhism, but most scholars believe that it developed independently. 
development is ongoing. It was accepted by the government in $1978 .{ }^{17}$ It has sacrificed its non-theistic perspective of nirvana or universal emptiness, which is now interpreted to mean that nothing ultimately exists except God. Currently, the goal is for practitioners of Buddhism to be role models for peace and helping the world, so that people will say a good person is "like a Buddhist". ${ }^{18}$

One form of syncretistic Buddhism in Indonesia is called Tridharma. The name "tridharma" refers to its three religions or dharmas: Buddhism, Confucianism, and Daoism. While Daoism is in the process of finding a monotheistic God in its sacred texts (thus far they have managed a goddess), Confucianism has already done so. It, too, has become an official monotheistic religion, called Agama Konghucu Indonesia, but for many years Confucians had to worship under the auspices of Tridharma Buddhism. According to Konghucu theology, there is one God, Shang Ti or Tian. This is understood as the earliest God known from China, the ancestral God of the Shang dynasty. The Analects are interpreted in a monotheistic fashion, and this was understood to be the perspective of the prophet Confucius. He was one in a series of prophets of Chinese Ru religion, perhaps the most well known.

The Ru religion is based on the Confucian God who is formless, neither male nor female, and worshipped with prayer, incense, singing, reading scripture, and confession of faith (belief in one God, upholding virtue, following the bright word of God, having full devotion, following the teachings of Confucius, and glorifying scriptures). The 1982 Book of Confucian Hymns includes "I am Praying", "Deep into the Heart", and "Remembering the Birth of the Prophet". ${ }^{19}$ Confucius' mother is also accepted as a prophet, and she saw the mythical Qilin dragon in a dream when Confucius was born (it predicts the birth of a prophet). In Indonesia, though Confucius is considered the last prophet of the Ru tradition, later prophets of other traditions are also to be honoured.

As high priest Xs. Buanajaya noted in interview that Confucianism has been described in Indonesia from the seventh century. The traveller Fa-hsien was in Indonesia before the Srivijaya period and met Chinese followers. According to tradition, a Confucian believer in God should be "inwardly like a prophet and outwardly like a wise king". The basic rules are to act justly, follow a moral life, and love people. One is to honour first one's father, mother, and ancestors; next one's sisters and brothers; next one's country and leader; and next one's friends and all of humanity. The Ru tradition was originally a royal religion, but later it became public. Originally, the emperor worshipped God, and his subjects worshipped the ancestors, but it was since democratized so that all members of Confucianism worship God. There are

17 Ashin Jinarakkhita proposed the name Sanghyang Adi Buddha as the name of God in the teachings of Buddhism. It was then submitted to the Ministry of Religious Affairs and the Government finally accepted Buddhism as the official religion of the country in 1978. It is listed in the GBHN 1978, Presidential Decree Number 30, 1978.

18 Interview with Cornelis Wowor, Director of Buddhist Religious Affairs, Ministry of Religions, and professor at Sriwijaya Public College, Tangerang, 2010.

19 The prayer book was at the Confucian Temple in Tangerang. 
now four pillars of Indonesian Confucianism: 1. Belief in God; 2. Confucian philosophy; 3 . Education; 4. Morality in politics and ethics. The highest social goals of Confucianism are education and service to the nation..$^{20}$

Confucianism has had a difficult time in Indonesia, as it was at first accepted as legitimate and later "dereligionized", after the attempted government coup of 1965 was largely blamed on Chinese communists. ${ }^{21}$ Though Chinese communists disliked the Confucians (differing primarily in cosmology, understandings of social hierarchy and politics), their religion was still declared no longer legitimate in Indonesia. Confucians were forced to practice under the auspices of Tridharma Buddhism. When there was more sympathy towards the community, as there was later under Indonesia's president Abdurrahman Wahid, the religion became accepted again. A major marker of the official status of the religion is whether the president attends Chinese New Year celebrations. This uncertain status and fluctuating legality creates anxiety among Indonesian Confucians, and there have been riots over perceived Chinese wealth and landholdings. Confucianism has sacrificed its non-theism, and its dependence on China, for its Indonesian status.

It may be noted that the prophets for all of these religions come before Muhammad, who was the last of the prophets according to Islam. Thus, new religions with more recent prophets may have problems being accepted as legitimate revelations. However, they can be accepted as modern restatements of older ideas, and as such they may be placed within the more sociallyacceptable versions of aliran kepercayaan or streams of belief. A number of new religious movements, including Subud, the Brahma Kumaris, and the Sejati have recast their original revelations as newer versions of older monotheisms in order to be accepted by the larger culture.

\section{AGAMA HINDU DHARMA INDONESIA}

To give a more detailed example of the ways that religions have adapted to the government religious requirements, we can look at the situation of Hinduism. Agama Hindu Dharma, which has been accepted in Indonesia since 1958, is understood as a monotheistic religion. It went through a process of adaptation into monotheism in order to gain government acceptance, focusing on the One God as Sanghyang Widhi Wasa. In order to fit the government requirements, Indonesian Hinduism has one God, prophets (the rishis or Vedic sages) revealed texts (the Vedas and Bhagavad Gita), and an ethical system based on the Dharma Sastras or traditional law books. It has sacrificed its multiple

20 Interview with Xs. Buanajaya, High Priest and Tai Chi Grand Master, Tangerang, 2010.

21 From 1965-1968, religious rules were made much more rigid as part of Suharto's violent rise to power. Any religious beliefs which did not follow the rules of the central government during the New Order period were interpreted as threats to national unity. Being an atheist was illegal, and virtually a death sentence-the immediate assumption was that any atheist was a communist, and there were massive anti-communist riots in Indonesia (in 1965, 80,000 Balinese were killed in the October riots, and half a million to a million were killed throughout Indonesia). 
forms, both sectarian and non-theistic, to focus on ethical monotheism and dharmic or moral action. It has also incorporated a call to prayer, five pillars of belief, atonement for sin, and a greater opposition of spirit and matter.

While Indonesia is primarily Muslim, a small minority of Indonesians are Hindu, living primarily on the island of Bali (Bali is about $85 \%$ Hindu, with about four million people). To begin, we should take a look at the meaning of the term "Hinduism".

Hinduism is an umbrella term for a variety of Indian religions. Its major subtypes in India include shamanic or folk Hinduism (emphasizing animism and nature deities), Vedic Hinduism (which is polytheistic), Vedanta (which is monistic), Yoga (which is non-theistic or monistic, and in some cases dualistic), Dharmic Hinduism (which emphasizes the best way to live, and ranges from polytheistic to monotheistic), and Bhakti (which may be monotheistic or henotheistic). These types of Hinduism disagree on theology, ritual, institution, and religious experience-there is no single "Hindu" religion. Yet one has been organized in Bali.

Actually, there are several Balinese Hinduisms, including the Bali Aga tradition, folk and classical Agama Tirtha Hinduism, and modernized monotheistic Agama Hindu Dharma Indonesia. Bali Aga religion is restricted to small communities, while the other forms of Hinduism are followed more broadly.22 Agama Tirtha has both folk and classical dimensions. Its folk aspects involve worship of ancestors and the hyangs or spirits, and sometimes there are symbolic struggles between good and evil. Healing is performed by the dukun, who enters a trance state, and the various types of dukun and balian are contacted to heal people of many problems.

The more classical side of Agama Tirtha Hinduism makes use of lontar texts, written in Kawi or Old Javanese, and interpreted by Brahmin priests. The supernatural world is shown in plays, dances, processions and visual arts, and people follow purity and pollution rules. There is much focus on offerings to deities. Temples generally have several sets of prayers: to Surya, the local temple deity, to the nine ruling powers (associated with the directions), and to all divine manifestations. There are temples to Dewa Brahma (who created the world and knowledge through his sakti, Dewi Saraswati), Wisnu (who protects the world in awatar forms and is helped by his two sakti, Dewi Laksmi who gives happiness, and Dewi Sri who gives rice), and Dewa Siwa, who has the three aspects of Mahadewa or king of the Gods, Bhatara Guru who guides humanity, and Bhatara Kala who rules the time of death. The major authority figures are Brahmin high priests or pedandas, who can change ordinary water into holy water, which can heal and bless. As Ida Bagus Putu Suamba has noted, they continue the religion of Javanese Saivism in the Balinese context. ${ }^{23}$

On holidays, deities who are normally in the heavens are called down into statues, and people honour them. They may go from a closed shrine to

22 For a discussion of the political, religious, and economic issues involved in the Bali Aga group, see Reuter (2002).

23 Interview with Ida Bagus Putu Suamba, Hindu University of Indonesia, Ubud, 2012. 
open space or from one village to another, accompanied by processions of offerings, especially pyramids of fruits. There are guest houses of bamboo made for visiting Gods. ${ }^{24}$ Deities are dressed for worship, given flowers and clothing, and carried in a palanquin-they should not touch the ground. The designs for the statues are made by inspired artists. Offerings are determined by desa (place), kala (time), and patra (tradition). High Gods are given holy water and five colours of rice, low spirits get coconut leaves with rice wine, and the Barong gets images sculpted of ground pork, with seeds and grains.

Many scholars estimate that both Hinduism and Buddhism initially arrived from India by about the fifth century $C E$, and were fused into a Hindu-Buddhist religion. There were several sub-groups of each, and a popular origin story describes the origins of Agama Tirtha Hinduism as a negotiated synthesis. Nine Hindu sects are said to have existed in Bali: in the older spellings, they are the Pasupata, Bhairawa, Siwa Siddhanta, Waisnawa, Bodha (Buddhist), Brahmana, Resi, Sora (Surya), and Ganapatya schools. Each group worshipped a specific deity as the primary God. It was said these sects competed with each other to be the dominant one, trying to make their respective Gods the ultimate deity of the island. Under the leadership of Mpu Kuturan, there was a gathering at Samuan Tiga temple in the late tenth or early eleventh century which gave birth to the belief system later known as Balinese or Agama Tirtha Hinduism. The participants agreed to unite the principles and teachings of their belief systems into a single philosophical and ritualistic entity with three major deities; Brahma, Visnu (Wisnu), and Siva (Siwa). The pantheon, rituals, offerings, and cosmology of this "new" religion included the main elements of every group, and it also included elements of Balinese folk religion. It provided a single, syncretistic form of Hinduism which could be broadly accepted. ${ }^{25}$ It was called Agama Tirtha, as all groups agreed on the importance of tirtha or holy water. ${ }^{26}$ This mixture contained primarily folk and dharmic aspects based on our earlier categories. This form of Hinduism was the precursor for Agama Hindu Dharma Indonesia.

There is a variety of theories of how Hinduism first came to Indonesia. ${ }^{27}$

24 Interview with Pinda, describing local ritual practices, Ubud, 2010. We may note that the Gods have developed a taste for exotic fruits, like Washington apples and green grapes from Australia.

25 This story is so popular that in 2011, Empu Kuturan and the origins of Agama Tirtha were commemorated in a large celebration, "Sharing art and religiosity: 1,000 years wisdom of Samuan Tiga" in Gianyar. (See "Keharmonisan beragama di Samuan Tiga", Kompas, 2 May 2011.)

26 There are many types of holy water in Bali. Water temples are found spread over irrigation systems and there are festivals held in these which celebrate "water openings" to flood fields downstream. Later festivals come at important times in the agricultural calendar, such as planting, transplanting, and the appearance of certain stages of grain.

${ }_{27}$ I Gusti Putu Phalgunadi describes four of these, using the metaphor of the caste system. According to the Vaishya theory, Hinduism came with traders and merchants from India, whose trading voyages often included intermarriage with Indonesians. In the Kshatriya theory, defeated warriors and soldiers fled India with their followers to take refuge in Indonesia and build up an alternative foothold in the area. The Brahmana theory posits that priests and missionaries from India spread the religion, and that it was accepted because these people 
The religion influenced Indonesian kings and warriors, and there were both Hindu and Buddhist kingdoms on the major Indonesian islands (Sumatra, Java, Bali, and Kalimantan). The most influential Hindu kingdom was the Majapahit empire, which reached its peak in the fourteenth century. However, Hinduism lost its status as the dominant religion during the fifteenth and sixteenth centuries, as the Majapahit empire was conquered by the Muslim sultanates. As the Majapahit kingdom disintegrated, many of its priests, artists, musicians, and leaders moved to Bali. Foreign merchants were attracted by the spice trade (primarily pepper, nutmeg, and cloves), especially Portuguese and later Dutch traders. Dutch seamen came to the islands of Bali and Lombok in the sixteenth century, and in the following centuries the Dutch East Indies Company came to dominate much of Indonesia. ${ }^{28}$

When Indonesia gained official independence from the Dutch in 1949, the island of Bali was integrated into the Republic of Indonesia, and religious problems became apparent. Balinese religion was classified as "tribal" or uncivilized, and thus not an agama or legitimate religion. ${ }^{29}$ In order to be accepted by the government, Balinese Hinduism had to change. It had to fit the rules of the Pancasila, and the requirements of the Ministry of Religion.

Realizing their religious situation in the new country, Indonesian Hindus were ahead of the curve. Hindu Balinese intellectuals came together in a council, the Parisada Hindu Dharma Bali, to reformulate Hinduism to fit the criteria set down by the government. One God was called the Almighty God (the others were equated with angels), the Vedas and the Bhagavad Gita became the equivalent of the Qur'an or the Bible, and the Vedic sages or rishis became the prophets. A philosophy and theology was developed, based on South Indian Saiva Siddhanta, with a strong emphasis on ethics and national identity, and the Parisada promised to emphasize texts and theology, and to simplify ritual. This idea was spread through a sustained public relations campaign in the 1950's, using radio ads, lectures at universities and social clubs, newspaper columns, and later televisions ads. By the time the request for acceptance as a monotheism was submitted to the government, everybody already knew that Hinduism was monotheistic, and it was not controversial.

The early Parisada members had analyzed sacred texts to find a monotheistic basis for Indonesian Hinduism. They chose a Vedanta/Saiva Siddhanta model, and called the God Sang Hyang Widhi Wasa. This was a

were believed to possess supernatural knowledge and power. The Bhumiputra ("native son" or nationalist) theory places the origin of Indonesian Hinduism in Indonesians who visited India, liked the culture, and brought back religious ideas. Indonesia (especially Bali) is mentioned in such ancient Indian texts as the Ramayana, the Brahmanda Purana, the Vayu Purana, and Jataka Tales. In these texts, Bali is usually called Suvarnadvipa or Svarnabhumi. In the collections of stories in the Brihatsamhita and Kathasaritsagara, Bali is called Narikeladvipa, the island of coconuts. India was the source of the kavi (from the Sanskrit kavya) literature, which included the epics (the Mahabharata and Ramayana), the puranas and the Vedas, and which are still considered sacred texts in modern Indonesian Hinduism. The dating of these ancient texts is much debated by scholars. See Phalgunadi (1991: 26-33).

28 Charle (1991: 33).

29 Howe (2001: 147). 
uniquely Indonesian name, emphasizing the importance of the nation and its language, with a God who could be worshipped by both Saivas and Vaisnavas. The name Sang Hyang Widhi was popularized as an equivalent to the Malay word Tuhan, meaning Lord, and was officially adopted as the name of God in the early 1950's. Some Christian missionaries had adopted that name to translate the Christian conception of God into the Balinese language, and thus the name was known to other religions. ${ }^{30}$

The Parisada Dharma Hindu Bali began officially in Denpasar, Bali, in order to support the rights of Hindus in Bali. Its strategy for getting acceptance for Hindu monotheism made use of the media of the time. It spent years as an informal organization, putting on radio broadcasts, lecturing, and using other media describing the Hindu God as a single, universal God, and monotheism became the popular understanding of Hinduism. Balinese Hinduism was accepted by the Indonesian government as an official religion, as Agama Hindu Bali, and continues to be regulated by the Parisada, to keep the religion in conformity with government requirements. ${ }^{31}$

The original group consisted of Hindu academics, writers, government officials and priests. It had an 11-member council of priests, a 22-member council of experts, and an executive committee with a pedanda (Brahmin high priest) as president. The academics argued for innovation, while the Brahmin priests focused on tradition, training other priests and writing interpretations of sacred texts. ${ }^{32}$ In this case, the academics perspective came to dominate. In 1964 the group sought a less regional focus, and became the Parisada Hindu Dharma. This was intended to include Hindus in Java, Sumatra, and Sulawesi. Agama Hindu Bali was then called Agama Hindu Dharma, in order to broaden the religion to Hindus outside of Bali. In 1986 the group became the Parisada Hindu Dharma Indonesia (PHDI), as an all-Indonesia religious group. ${ }^{33}$

The Parisada works through the Departemen Agama or Indonesian Ministry of Religious Affairs. Like the Dutch, who maintained Indonesia as a colony until the time of Indonesian independence, the Indonesian government has a department dealing with religion. It consults with the government leaders on problems or issues relating to religion in the country.

In 1987, the group organized and instituted thirty-day training courses for priests, which ran every six months. Each group had about fifty students per class, and they developed a series of textbooks on Hindu priesthood. Today, the Information Office of Agama, Adat, and Budaya (Religion, Custom, and Culture) deals with the media, and approves the ordination of priests and religious professionals. They handle the certification of pedanda and pemangku or mpu (lower or temple priests), and they organize courses for the priesthood.

30 According to the Sanskritist Jan Gonda, "in modern Bali Vidhi (Viddhi) - the Indian designation of "rule, destiny" which is also applied to some individual Gods - denotes that principle which, representing the unity of the universe is beyond all plurality and acts as the guardian of the cosmic and moral order".

31 Picard (2004: 56-75).

32 Bakker (1993: 299).

33 Ramstedt (2004). 
While the high priests learn primarily from their gurus, and are routinely approved if the guru supports them, the lower priests must attend a one-month priest course (usually taught in July or August). According to I Gede Potha, about fifty priests per year take the course, which includes ritual, theology, and the proper relationship of religion and government.

Currently, the Parisada is a largely volunteer organization, with both lay members (including civil servants, who get time off from their jobs for Parisada work) and priests. It organizes times for festivals (which is important, as Bali uses several calendars), and makes local theological and ritual decisions. ${ }^{34}$ It is the link between the Ministry of Religious Affairs and the practitioners, and balances Indian Hinduism, traditional Balinese Hinduism, and Agama Dharma Hinduism.

As for the name Sanghyang Widhi Wasa, its origins are somewhat obscure - some writers say the term referred to a Balinese God, while others say it was made up at the time of the Indonesian constitution as a monotheistic term for Brahma or Siva, still others claim that the term came from Dutch Christian missionaries trying to translate the God of the Christian Bible into Balinese. In modern Indonesia, Sanghyang Widhi Wasa is the one eternal and almighty God, and the other Gods are understood to be only his emanations. We should note that Sanghyang Widhi Wasa does not have temples or images of his own, as he is mostly understood as without form or nirguna, a deity who is accepted but unseen. However, modern Balinese Hindu temples have been changing, and several temples in Bali have developed a special shrine to him, which is empty, in the northeast corner of the temple. Sanghyang Widhi Wasa is occasionally represented by a sketch or a statue, a person with no gender or clothing, but with flames that represent energy or sakti emerging from chakras. This image is also starting to appear on altar cloths and other ritual items. ${ }^{35}$ However, many artists say that he cannot be represented, for he is beyond form and acintya (imagination).

In a political and theological metaphor, there are many levels to the government, and God is understood to be like one government with many departments. ${ }^{36}$ The unity and multiplicity of God is reflected on earth through hierarchy and organization. The government is reflected in the desa adat, the group that determines and is responsible for village ritual life. The local laws must fit with the state laws, and society may be compared to a body, and to a family, where all parts must work together in harmony.

The modern form of Hinduism bears a strong resemblance to Islam in several ways. There is one God, whose texts were revealed to sages and written in sacred languages (Sanskrit and Kawi, or Old Javanese). There are three prayers a day (the trisandhya), which deal with sorrow over sin and God's forgiveness. There is devotion to the four teachers or gurus-God,

\footnotetext{
34 These involve the Indian Saka calendar, which is lunar, and the Wuku year of 210 days.

Interview with Pinda, Ubud, 2010.

A memorable quote from Gusti Agung Gede Putra. Cited in Bakker (1993: 190).
} 
parents, schoolteachers, and the government. Devotion to the government thus becomes a part of the religion-another area of compromise. There are also five pillars of belief (in brahman, atman, karma, moksa, and samsara) and five pillars of practice or yadnya (offerings to God, to ancestors, to people and society in the life cycle rites, offerings to propitiate destructive spirits, and offerings to sages in the rites of ordination). Pilgrimage is also important, to sites in both Bali and India. Religion is a compulsory topic taught in the schools, with a heavy emphasis on ethics and obedience to authority, and children must attend school for six years. ${ }^{37}$ True religion is understood to be revealed by God, the sign of a "religion of heaven", as opposed to ethnic "religions of the earth" which are man-made.

The Ministry of Religious Affairs has two major sections or offices. One is the Education Office, which handles curricular issues in the schools, and the training of teachers. The other is the Information Office, which is the liaison with the community and with society at large. It has five major sections for the five accepted religions (the organization of monotheistic Confucian education is still in process). Its Hindu section works though the PHDI and the school system.

I interviewed members of the Ministry of Religious Affairs in Denpasar and Gianyar, as well as members of the Parisada and school officials and teachers. According to I Gede Potha, a representative, there are several major reasons for the department's existence. Its most important one is conflict resolution between major religious groups, and sometimes within the religions themselves. If there is fighting, the department has mediators who can step in as outside authorities and make peace. Another reason is for counselling within religions, as a part of the process of peacemaking. It also organizes educational conferences and meetings with religious representatives, to maintain interfaith dialogue. It has a special section for public relations to speak to the media and clarify religious misunderstandings, and also a section for training teachers and priests. ${ }^{38}$

According to I Gusti Made Arya, a professor of Hindu philosophy and religion and Parisada representative, in Hinduism God is all-pervading, less personal than in the Western religions, following the nirguna brahman concept from Vedanta philosophy. The Parisada is studying the ways that religion can become a force for peace in society. Currently the PHDI is discussing a change in Hindu religious law, the development of a Hindu sharia, as the basis of a new personal law. They are also debating whether to have consistent temple rituals, offerings, temple clothing, architectural styles, religious music and liturgy. Greater organization could incorporate all aspects of Hindu Dharma, including devotion to God, and including the worship of ancestors as a part of the worship of God. Arya stated that monotheism was a good approach, as it can be easily taught to children, and when they understand that God is everywhere, they will understand that they should respect nature and not

38 Interview with I Gede Potha, Department of Religion, Denpasar office, August 2002. 
destroy the environment, and care for others, as the basis for a better world. ${ }^{39}$

The modern adaptations of Agama Hindu Dharma are still controversial among practitioners, as their approach is quite different from that of traditional Balinese Hinduism. But Indonesian Hinduism has accepted the dominant categories of discourse and religious structure, and it has shown that it can adapt to those requirements. As such, it has become a recognized religion, with the safety and support that such status can bestow. It shows one of the positive results of the Pancasila idea, and a situation with less religious violence than on many islands, a situation in which common categories of belief and knowledge can create a situation of interfaith dialogue and national acceptance. The Ministry of Religion and the PHDI have generally been able to perform their functions of encouraging harmony and mediating disputes.

\section{FREEDOM OF RELIGION, MODERNITY, AND MORALITY; A DISCUSSION}

However, modernity is always stressful on cultures, and not all groups within the culture find it easy to adapt. While positive and rapid adaptation can be easily seen in the fields of technology and medicine, other fields have been more resistant to change, and move more slowly to incorporate and evaluate new ideas. In the United States, religious groups which resist modernity and seek to focus the lives of their followers on the past, and on ancient or inspired religious texts which are understood to be absolutely true, are popularly known as fundamentalist groups.

In both the United States and Indonesia, we can see an important problem of fundamentalism. This is the idea that one's beliefs are primary, and one's works or actions in the world are less important. This can be interpreted to mean that God will tolerate violence and dishonesty as long as one claims belief in Him, and He will forgive bad behaviour by sinners, while condemning others who have good behaviour for their lack of belief. In the Christian tradition, the exclusive focus on salvation by faith through God's grace was a major reason for the split between Protestant Christianity and Catholicism, as the person's beliefs came to be viewed as more important than his or her actions. There are Christian fundamentalist groups who reject modernity and portray God as warlike, not the "Prince of Peace", but a general who leads troops in the apocalyptic battles at the end of time. They see the world as full of enemy belief systems and themselves as warriors defending the one true faith.

In Indonesia, we seem to have the same struggle between faith and works. In the popular literature, we see a distinction between "believers" and "nonbelievers," with the assumption that believers are always good because of their faith, while non-believers are always immoral because they do not have

39 Interview with I Gusti Made Arya, Sekolah Tinggi Agama Hindu, Jakarta, 2010. He also notes that the name "Sanghyang Widhi Wasa" emphasizes the nirguna or formless aspect of the deity, and is a translation of the Sanskrit term Brahman into Balinese. Sanghyang is a Javanese term for 'ancestral spirit' (sang meaning 'the', hyang meaning 'spiritual'), while widhi comes from vidya 'highest wisdom', and wasa from the Javanese term for'the strong one'. Thus, Sanghyang Widhi Wasa is 'the strong one of highest knowledge and spirituality.' 
the right faith. This is a problem of theology, in which a narrow focus on faith can tolerate or even justify violent and dishonest action.

As an example of this genre of writing, we have the cover theme for the Indonesian magazine Campus Asia, "Moral decay ruins society as schools abandon religion". Pitan Daslani's article "Already Atheism is a plague on modern societies", describes all killers, criminals, rapists, and liars as atheists. He blames their lack of morality on hedonistic soap operas and television stations which broadcast shows on animism. ${ }^{40}$ Ferry Yang's article "Schools have failed to develop morality as secularism intensifies", notes that people hide behind religious masks, but are often immoral. He blames this lack of morality on the lack of religion in the schools. ${ }^{41}$ In his article on "Hypocrites claiming to be religious", Azyumardi Azra comments on the split in moral perception in Indonesia, where private morality justifies public immorality. He notes that religious education emphasizes theory over practice, and suggests that perhaps there should be a jihad against corruption. ${ }^{42}$ Problems include a lack of punishment for bribery and corruption, poor role models in the media, and the lack of strong moral figures who challenge hypocrisy and lies.

All of these writers have good arguments, but I would suggest that there is another deeper problem behind those mentioned (Azra's article implies it). This is an ancient theological problem: when faith is more important than works, good faith can be used to justify bad works. As Yon Machmudi noted in interview, members of violent groups like the FPI (Front Pembela Islam) are often told that their sins of selfish violence in the past can be forgiven by God - if they do the same violent acts to support God. ${ }^{43}$ Thus, harming women and children in riots can be justified because you have the right faith. With the philosophy of "preaching by force is best," violent Islamist groups give parttime jobs to unemployed people, who surrender to their authoritarian leaders. With selective enforcement of law, they are often able to harm people at will.

We see the same tensions between faith and works in the 1965 Blasphemy Law (upheld in 2010). Under this law, people who do good action in the world can be prosecuted for wrong beliefs. This law has not only been used to prosecute people who insult and harm religious believers (what in the United States might be called "hate crimes") but also towards people who interpret religious ideas in different ways from the dominant religious groups - what we might call "thought crimes", following the writer George Orwell. ${ }^{44}$ There

$40 \quad$ Daslani (2010: 76-77).

$41 \quad$ Yang (2010: 88-89).

42 Azra (2010: 90-91).

43 Interview with Yon Machmudi, University of Indonesia, Depok, 2010. He also noted that many Muslim groups who advocate violence are charismatic in style, with an authoritarian leader who represents God for the members. If the leader likes him, then God will like him - so the follower should be as active, and destructive, as possible to gain his attention.

$44 \quad$ In his book 1984 - Nineteen eighty-four (London: Secker and Warburg, 1949), George Orwell describes a society of perpetual war and public mind control, headed by the figure of Big Brother. People were punished for their thought crimes, which showed individual thinking, especially doubts about the dominant political party. The Thought Police would find and punish thought crime. People were punished, not for their actions, but for their thoughts. 
is total focus on belief, even when the people involved have done no harmful public actions at all. People are condemned for having religious visions, for original understandings of the relationships between different forms of God, and for believing in unpopular prophets and philosophies. This problem of policing thought is particularly found in the Bakor Pakem (Badan Koordinasi Pengawasan Aliran dan Kepercayaan Masyarakat or 'the Coordinating Board for Monitoring Mystical Beliefs in Society'), under the Attorney General's Office. It observes the aliran kepercayaan groups, to determine which are allowed and which are not allowed, determining if they are insufficiently monotheistic. Again, the issue is not if they have harmed people or performed any criminal activities. The fundamentalist concern with faith makes behaviour less important, and groups are primarily condemned for their thoughts and their world views, not for their actions.

Belief in a God may lead to good, moral action-or it may justify violent and immoral action. Belief in God can work both ways. Religious faith has an influence on moral behaviour, but it does not determine it. We find political and social corruption in many religious cultures, especially when theologians can justify it by God's greater concern with other issues-and with the pragmatic argument that "the end justifies the means".

Modernization has become a scapegoat for immoral behaviour around the world, and this has led to the rise of fundamentalism with its reverence for the past in the world religions. However, technology and globalized markets do not determine whether a person will be honest or dishonest. Exposure to other religious views may make people confused or hostile, but it may also make people more thoughtful and tolerant. Morality may be based on the hope of heaven, but for most world religions, it should also be based on compassion for others and sharing a good life while on earth.

Another problem relating to modernization may be found in the 2005 condemnation of pluralism, liberalism, and secularism by the Indonesian Ulama Council (MUI), which was supported by the Ministry of Religious Affairs. It is an issue in which translation of terms seems to be a major problem, this decision does not make sense in the modern uses of the English language.

In modern English, pluralism implies respect for all religions, it is "a situation in which people of different social classes, religions, races, etcetera are together in a society but continue to have their different traditions and interests" and "the belief that people of different social classes, religions, races, etcetera, should live together in a society" ${ }^{45}$ This can be seen in the well-known Pluralism Project at Harvard University, where diversity is studied, but there is no equating of religious truths. However, Atho Mudzhar of Jakarta State Islamic University stated in interview that the Ministry supported the MUI condemnation of pluralism because it meant that all religions were equally true, and this meant disrespect for your particular religion. ${ }^{46}$

45 Online at http://www.merriam-webster.com/dictionary/pluralism.

46 Interview with Atho Mudzhar, Jakarta State Islamic University, Jakarta, 2014. He was the former director for development of Islamic religious education in the public schools for 
Now, "all religions being equally true" is not the popular definition of the word "pluralism" in modern English - this is the popular definition of the English word "universalism". But the underlying assumptions are also problematic - if you honour all religions, why would this mean disrespect for your own? Honouring all religions would certainly include your own religion. If you say that you should only respect your own religion, and disrespect others, is this not supporting bigotry and religious prejudice ${ }^{47}$ Indeed, this contradicts both the 1945 Constitution of Indonesia, chapter 29, which supports religious freedom, as well as the Qu'ran, "Let there be no compulsion in religion" (Q. 2. 256). ${ }^{48}$

As Hilaly Basha (2011) notes, many scholars have recognized that the definition of pluralism used in the fatwa is confusing, and not accurate to modern usage. He quotes the fatwa: "Pluralism stipulates that all followers of religions will enter and live side by side in heaven". No popular English definition of pluralism believes this; again, this is describing the concept of universalism, which believes in universal salvation. He notes that this claim of pluralism being haram has motivated attacks by intolerant and violent groups (Basha 2011: 79). Defining words properly in legal judgments is extremely important, for it can have this sort of result.

Liberalism is also condemned, and here too we have problems in language. In modern English, we have political, academic, and religious understandings of the term "liberalism". The concept of liberalism is generally opposed by the concept of conservatism. On American conservative talk radio, political liberalism is described in negative terms. This is largely because, from the conservative perspective, the government should not focus on compassion but rather on competition. The conservative approach is generally not comfortable with change, and prefers to look back to a time that is considered to be a better one.

In colleges and universities, liberalism is associated with the liberal arts: literature, music, and art, expressions which are unique to the culture. Would being against liberalism mean that Indonesians should not study the liberal arts of their own culture? The religious understanding of liberalism involves human rights, social justice, free will, and compassion. Is Indonesia against human rights and social justice? These are in the Pancasila. Probably the most popular definition of liberalism, though, is the political one: "belief in the value of social and political change in order to achieve progress" ${ }^{49}$ Would a

the Department of Religion, and the founding director for the Islamic University Department of Religion.

47 Interview with H. Mubarok, Head of Indonesia's National Center for Inter-Religious Harmony, Jakarta, 2014. Mubarok emphasized the importance of religious freedom and de-radicalization in Indonesia, and he was a clear and reasonable speaker. However, the condemnation of pluralism with which he must deal does not seem to harmonize with this view.

48 These points were made by Muhamad Ali, "The impact of MUI fatwas on freedom of religion in Indonesia", The Jakarta Post, 8 August 2005.

${ }_{49}$ Online at http://www.merriam-webster.com/dictionary/liberalism. 
condemnation of liberalism mean that Indonesians are against change and progress?

Secularism might be a clearer area for a fatwa, as popular English definitions imply either non-belief in religion, or placing religious practice in the private rather than the public sphere. But secularism also implies belief in science and technology. Would Indonesia wish to reject modern medicine, cars, and computers? This is another area of debate, and again shows problems of language.

The Indonesian government has had to walk a narrow line of compromise. If they are too liberal and accepting of other religions, they fear that Islamist crowds will punish people on their own without government sanction, and there will be vigilante justice. Thus, the government is retaining the law against blasphemy. Too much freedom can mean a lack of responsibility, and ignoring concerns about morality. But if the government is too harsh and intolerant, it loses the idea of religious freedom, which is guaranteed in the constitution. Then the state would move towards authoritarian rule. It would be useful if the blasphemy law could be amended to focus on specific actions, rather than just on personal belief. Some clarity on the differences between "hate crime" and "thought crime" would be helpful, and changing the wording of the pluralism fatwa might lessen confusion and violence.

These are issues that Indonesia needs to address. But from the world perspective, what is perhaps most important about the Indonesian situation is the impressive ability of its religions to compromise. Muslim theologians are willing to say that the 99 names of God are a minimum, not a maximum - thus other religions can reflect God's true nature. We have an Islam that has found a way to live with other religions in mutual acceptance, and a Christianity that can accept pluralism. We can see the important contributions to theology of thinkers like Nurcholish Madjid and Zainum Kamal, who study areas like figh (ritual, morality, and law), ijtihad (theological interpretation), and tafsir (exegesis), to show that the Qur'an can legitimately be understood from a broad as well as a narrow viewpoint. In their book, they argue that many People of the Book can be viewed as righteous, and that the names and prophets of God are not as few as are often claimed. ${ }^{50}$ Here modernization would involve arguments from the Qur'an.

Masykuri Abdillah places his emphasis upon the cultural dynamism of the Indonesian people, and rejects the religious and cultural dominance of foreign forms of Islam like Wahhabism. He finds Indonesian Islam to be compatible with peace, democracy and pluralism, and believes that it can modernize by harmonizing Islamic ideas with science. It needs a stronger theological basis for tolerance, and role models to teach morality through experience; it should include data on the development of ideas, and the role of Javanese theories of politics and ethics. His suggestion for modernizing Islam would be multi-faith education, with classes teaching religious harmony and civic education, teaching students about the constitution and the political 
parties. Classes should avoid absolute claims that lead to violence, portraying groups as enemies, and focus on faith that comes through personal choice. His understanding is that "the mission of Islam is blessing the universe". ${ }^{51}$

Azyumardi Azra discusses a similar problem, the misunderstanding and romanticizing of history by Islamist groups. They idealize the fighting from the early days of Islam, but they need to study the commentaries and opinions of the ancient ulama to understand the meanings of historical events over the course of Muslim history. In the modern world, we have polemical preaching by both Muslims and Christians, especially converts, and Indonesia needs to empower its moderates. There is a need to strengthen multiculturalism and religious dialogue, with ministers who support tolerance and consistent law enforcement across different religious populations. Religious groups should follow the voluntary compromise of the Pancasila, to live in a peaceful country. ${ }^{52}$

Hilaly Basya argues for progressive Salafi Islam, and accepting the history of ideas and the study of social and political theory as a part of the study of Islam. His approach is that the study of the Qur' an should include hermeneutics and context to understand its message, and that Muhammad's talks with the Muslims of his time after prayers are a good basis for democracy. Scholars of the Qur' an need to determine which statements in it are responses to historical events, and which represent rituals and ethics that are to be applied in all times and places. Law in the Indonesian context needs to be inspired by local ideas, as well as Islamic doctrine, as the basis for a stable religious identity. ${ }^{53}$

Fajar Riza uf Haq notes that the idea of "Dawa Kulturen", or the cultural spread of Islam, should be engaged as a counter to Arabization. This would strengthen national identity, and empower the Pancasila, thus revealing both the ancient wealth of Indonesian culture and its global responsibility as a developer of a temperate and peaceful Islam that can be emulated by other countries. The emphasis on the Indonesian form of Islam would balance the influence of violent extremists, who have been giving the mainstream Muslim organizations a bad image in the press. Many "born-again" Muslims, who were secular and learned Islam from Wahhabis, are trying to change Indonesian culture into Arab culture. Indonesia must also avoid following the Turkish model, moving slowly from democracy towards an authoritarian system, and it should support indigenous Islam rather than foreign forms of the religion. ${ }^{54}$

While there are violent Islamist groups of various ssots (states sponsors of terrorism) in Indonesia, these are generally not accepted by the government or the population at large, despite the prevalence of advertising for religious

51 Interview with Masykuri Abdillah, Deputy Secretary General of International Conference of Islamic Scholars (ICIS), Jakarta, 2010.

52 Interview with Azyumardi Azra, Director Graduate School, State Islamic University, Jakarta, 2010.

53 Interview with Hilaly Basya, Muhammadiyah scholar, Jakarta, 2010.

54 Interview with Fajar Riza uf Haq, Jakarta, 2010. 
and political extremism. Indonesia may well be the most successful multireligious Islamic-majority state currently existing, and as Muslims throughout the world seek an alternative to the Arab model of Islam, it may contribute to the development of more moderate Muslim theologies. It is also a place of impressive theological creativity in the world religions, which have created a set of uniquely Indonesian religious ideas. This is not always visible in Western writing on Indonesian religion, which tends to focus on religious and political violence.

The Pancasila and the theologies based on it are examples of religious compromise, based on the standardization of a definition of religion. They are a unique and significant contribution to the world discourse on religion and culture, as a political, philosophical and theological basis for peace, which has been accepted by a democratic country. It is an important question as to whether the Indonesian view can challenge the wealth and media pressure of more extreme forms of Islam, and maintain freedom of religion expressed in the Pancasila doctrine and the Constitution.

\section{REFERENCES}

Azra, Azyumardi. 2010. "Hypocrites claiming to be religious", Campus Asia 3(14): 90-91.

Bakker, Frederik Lambertus. 1993. The struggle of the Hindu Balinese intellectuals; Developments in modern Hindu thinking in independent Indonesia. Amsterdam: Vrije Universiteit Press.

Basha, Hilaly. 2011. "The concept of religious pluralism in Indonesia; A study of the MUI's fatwa and the debate among Muslim scholars", Indonesian Journal of Islam and Muslim Societies Vol. 1(1): 69-93.

Charle, Suzanne. 1991. Bali; Island of grace. Lincolnwood: Passport Books.

Daslani, Pitan. 2010. "Already Atheism is a plague on modern societies", Campus Asia 3(14): 76-77.

Efimova, Larissa M. 1996. "The state ideology Pancasila as a manifestation of religious revivalism in contemporary Indonesia", Temenos 32: 55-63.

Howe, Leo. 2001. Hinduism and hierarchy in Bali. Santa Fe: School of American Research Press.

Intan, Benjamin Fleming. 2006. "Public religion" and the Pancasila-based state of Indonesia; An ethical and sociological analysis. New York: Peter Lang. [American University Studies. Series VII. Theology and Religion.]

International Religious Freedom. 2011. July-December, 2010 International Religious Freedom Report - Indonesia, 13 September 2011. United States Department of State. [Available at: http://www.refworld.org/ docid/4e734c9282.html.]

Kamal, Zainun, et al. 2006. Interfaith theology; Responses of progressive Indonesian Muslims. Jakarta: International Center for Islam and Pluralism.

Phalgunadi, IGusti Putu. 1991. Evolution of Hindu culture in Bali: from the earliest period to the present time. Delhi: Sundeep Prakashan. 
JUNE MCDANIEL, Indonesia, modernity and some problems of religious adaptation 335

Picard, M. 2004. "What's in a name? Agama Hindu Bali in the making", in: M. Ramstedt (ed.), Hinduism in modern Indonesia; A minority religion between local, national, and global interests, pp. 56-75. London: Routledge Curzon. [IIAS Asian Studies Series.]

Ramstedt, M. 2004. "Introduction; Negotiating identities - Indonesian "Hindus" between local, national, and global interests", in: M. Ramstedt (ed.), Hinduism in modern Indonesia; A minority religion between local, national, and global interests, pp. 1-34 London: Routledge Curzon. [IIAS Asian Studies Series.]

Reuter, Thomas. 2002. Custodians of the sacred mountains; Culture and society in the highlands of Bali. Honolulu: University of Hawai'i Press.

Silalahi, M.R.M. and Tore Lindholm. 2010. Protecting the One and Only God; A human rights assessment on Indonesian blasphemy law. University of Oslo, Faculty of Law. [Available at: https://www.duo.uio.no/bitstream/ handle/ 10852/22874/ThesisxCandidatexNo.x8030.pdf?sequence=1.]

Yang, Ferry. 2010. "Schools have failed to develop morality as secularism intensifies", Campus Asia 3(14): 88-89. 